\title{
Swedish mineral policy at a crossroads? Critical reflections on the challenges with expanding Sweden's mining sector
}

\author{
Simon Haikola and Jonas Anshelm
}

\section{Journal Article}

\section{Tweet}

N.B.: When citing this work, cite the original article.

Original Publication:

Simon Haikola and Jonas Anshelm, Swedish mineral policy at the crossroads?: The challenge to governmental attempts at expanding the Swedish mining sector, The Extractive Industries and Society, 2016. 3(2), pp.508-516.

http://dx.doi.org/10.1016/j.exis.2016.01.008

Copyright: https://www.elsevier.com

Postprint available at: Linköping University Electronic Press

http://urn.kb.se/resolve?urn=urn:nbn:se:liu:diva-125195

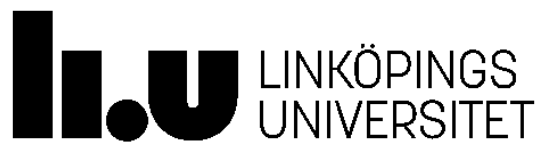




\section{Mineral policy at a crossroads? Critical reflections on the challenges with expanding Sweden's mining sector}

\section{Introduction}

In this paper, we reflect on the dialogue that has accompanied efforts made by the Government of Sweden to facilitate investment in the country's mining sector. Mineral prices have sharply increased in the twenty-first century. This has fuelled the rapid expansion of mining activities in Sweden, currently the largest mining economy in the European Union (EU), accounting for 91\% of its iron, $39 \%$ of its lead, $23 \%$ of its zinc, and $10 \%$ of its copper production. In 2011, the number of active claims and exploration permits reached an historic high, approaching 600 , over double $(<300)$ the number recorded in 2004. The most obvious sign of increasing interest in Swedish minerals was the rise in prospecting expenses, a figure which reached a record high of nearly SEK 800 million in 2011, over four times the amount ( $<$ SEK 200 million) recorded in 2002. Concerns over resource scarcity in the EU have underscored Sweden's potentially crucial role as a trustworthy source of metal ores in the region.

The country's mining policy has been designed with the objective of attracting an increasing share of the global venture capital flowing into the volatile but lucrative minerals market. This, however, has been met with opposition from certain national environmental non-governmental organizations (NGOs); local resistance groups; representatives from Sami organizations, the Sami Parliament and Sami villages; ${ }^{1}$ the tourism industry; and various academics, social scientists, and regional politicians. This resistance has focused on the Mineral Strategy launched by the government in 2013, a manifestation of the market-liberal ideas that critics claim jeopardize social, cultural, economic, and environmental values. Since the launch of the Mineral Strategy, global mineral prices have fallen precipitously, and the financial difficulties experienced by several new mining projects, notably Northland Resources, which declared bankruptcy towards the end of 2014, have further fuelled the debate about what kind of regulation should be imposed on the mining sector. In particular, the issue of financial guarantees for the restoration of mining areas post-production has been the subject of much discussion (see the Swedish National Audit Office, 2015).

As we will explain here, though this critique has been multifaceted and diverse, its core principles are in direct contrast to the ideas underlying the Government of Sweden's Mineral Strategy. This paper draws out the basic tenets of this critique, presenting them in the form of an alternative mineral strategy. We believe that an analysis of environmentally-motivated resistance is crucial to understanding technological and societal change, as the force of this resistance, whatever its form, helps to shape nations' technological and political development paths (see Anshelm and Galis, 2011). In this way, Sweden serves as an illustrative example for nations around the world looking to govern their mining sector using a firmly market-liberal approach (see Bridge and Jonas, 2002). The resistance in Sweden seems to reflect a global pattern, with reports indicating a growing number of mining conflicts globally (Shandl and Darbas, 2008; Storey, 2001; World Economic Forum, 2013; Özkaynak et al., 2013). Sweden merits special attention because of the frequent insistence of government spokespeople, industry representatives and policy critics who maintain that the country should set an example,

\footnotetext{
${ }^{1}$ The Sami people are an indigenous Finno-Ugric people inhabiting parts of northern Norway, Sweden and Finland, the border area between south and middle Norway and Sweden, as well as the Russian Kola Peninsula.
} 
globally, on the topic of "best practice" environmental and social aspects of mining operations. Our analysis of the critique of Sweden's current mining policy serves to gauge the validity of this assertion.

\section{Methodological and theoretical approach}

We qualitatively analyse a vast body of material comprising editorials and opinion pieces covering the 2012-2014 period, taken from major and regional daily newspapers in Sweden and the most important journals in the field. No news articles have been considered, though some longer news reports have been reviewed. The focus is on changes in official Swedish mining policy as manifested by the Mineral Strategy of 2013, and consequent investments in new mining projects in the study period. The identified texts were closely read, categorized according to a framework developed during the analytical process, and then reread. The analytical process was guided solely by the overarching purpose of identifying the main lines of conflict in current mining discourse in Sweden. As a starting point, we analyse the Mineral Strategy, which we understand as a paradigmatic text of the hegemonic mining discourse. Whereas the decision to treat the critical discourse could be criticized as one-dimensional, it serves our purpose of identifying the discursive struggles found in the framework of the country's new mining politics.

To gather the empirical material, we conducted truncated searches on the Retriever database using the search terms "mining industry", "mining company", "mining AND environment", and "mining policy OR politics". Though its coverage is not exhaustive, the database is sufficiently wide-ranging in that it is unlikely that we missed aspects of the critical discourse that would significantly alter our analysis. By reading through the 500 initial hits, we identified approximately 100 as critical of the government's Mineral Strategy, and of these we cited 54 to substantiate our claims. Note that the passages cited are simply examples that could easily have been supplemented given sufficient space. Furthermore, we did not attempt to distinguish between the actors, organizations, groups, and individuals making the cited critical statements; rather, we emphasised what unites all of these statements within the frame of the critical discourse, because the object of study is the discourse itself and not the actors constructing it or how it is reported in the media. The number of articles and associated authors are indicative of the increase in interest in the issues studied.

The terms 'mining policy' and 'mining politics' are both used in this paper. The former refers to the official policy of the Swedish government as set out in government proposals and other regulatory documents. The latter refers to the concrete actions and projects carried out by municipalities, mining companies, and other actors as well as to the oppositional actions of actors critical of the mining policy. In other words, 'mining politics' refers to the entire spectrum of activities carried out as the mining policy is implemented, including the discursive struggles analysed here.

Ontologically, we apply David Harvey's (2001) typology of six 'moments' of social processes: discourse/language, power, beliefs/values/desires, institution building, material practices, and social relations. There is neither space nor sufficient reason, for the present purposes, for a detailed philosophical discussion about the relationship between these moments. Suffice it to say that: 1) each moment of a social process relates dialectically to the others, meaning that 'discourses internalize in some sense everything that occurs at other moments' (Harvey, 2001: 80); and that 2) no general law dictates the pre-eminence of any moment over the others, which is not to say that no moment may or may not at any given time be relatively more significant for 
a given social process. While a discursive moment obviously does not have the direct material influence over the natural environment that an excavator has, it is equally obvious that actions taken using the excavator cannot be understood except in relation to the prevailing discourses and counter-discourses that surround and, in fact, largely constitute it. Harvey quotes Marx, often portrayed as holding material processes to be the sole ultimate determinants of social processes, as saying that it is in the realm of discourse that our understandings of political issues are formed and 'fought out' (Harvey, 2001: 92). The discursive moment scrutinized here holds in itself one of several keys to a thorough understanding of what is happening in Swedish mining politics today. The approach is similar to that of Bridge (2003), who sees the study of a particular discourse (in his case, mining legislation) as a normative struggle regarding how a particular territory should be ordered (see further Cox, 2005; Lefebvre, 1991; Smith, 1991; Yeung, 2002).

From this perspective, discourse analysis does not merely examine the reflection of material realities but examines a moment of social process in its own right, a moment that internalizes the relationships with all other moments (e.g., material processes and social relations) but is not reducible to them. Like Harvey, we believe that geographical and social space is infused with values through its reproduction in various social contexts, including the production of geographical knowledge through discourse. In this sense, the production of such space is also by definition a political act:

Social space, when it is contested within the orbit of a given social formation, can begin to take on new definitions and meanings. This occurs because the social constitution of spatio-temporality cannot be divorced from value creation or, for that matter, from discourses, power relations, memory, institutions, and the tangible forms of material practices through which human societies perpetuate themselves. (Harvey, 1996: 231) ${ }^{2}$

We study discourse as one of several moments of social processes in which mining politics and geographical space are being contested. That means, we do not perceive it as merely a representation of something more important, but as an object meriting study in its own right. It necessarily follows that our analysis of these discursive struggles must be complemented with analyses of how new Swedish mining politics are continuously reproduced and contested in other moments of social processes.

\section{The Mineral Strategy}

The national Mineral Strategy, rather awkwardly titled "Towards a sustainable usage of Swedish mineral assets, creating growth for the whole country" ("För ett hållbart nyttjande av Sveriges mineraltillgångar som skapar tillväxt i hela landet"), was launched in February 2013 with the explicit purpose of facilitating investment in mining operations in Sweden (Swedish Ministry of Enterprise and Innovation, 2013). The strategy is premised on a thoroughly market-liberal view of industrial expansion, the role of the state being identified as one of facilitating global capital movements (into Sweden) and stimulating market competition. While the government stresses

\footnotetext{
2 See also Haraway (2003), Harding (2006), Deloria and Wildcat (2001), Said (1979), and Gunder Frank (1967) for other scholars exploring similar issues using somewhat different ontological and epistemological approaches.
} 
the need for indirect state support in the form of investments in infrastructure, research, and education, the state is cast primarily as a passive actor whose most important function is negative (i.e., removing obstacles preventing the circulation of capital and the establishment of mining ventures). In terms of the Mineral Strategy itself, this entails speeding up the environmental approval process and abolishing taxes. ${ }^{3}$ In doing so, it is clear that the government is striving to create a conducive environment for mining ventures, to attract investment from around the world. Economic growth, international competition, and a rationalized and intensified extractive industry are all identified as national goals in the interests of all concerned. The possibility that some actors may have different ambitions and that mining policy may cause controversy is never acknowledged in the strategy. The strategy does, however, firmly stress the need for dialogue between concerned actors.

The selective employment of imagery in the Mineral Strategy is significant for how it conceals conflicts of interest, which are nevertheless implied by their very absence. Geographical visualizations consist primarily of maps, charts, and photographs of minerals and mines. Importantly, none of the images shows local communities affected by mining establishments. By concealing the actual places from which minerals are to be extracted, the Mineral Strategy privileges abstract space over lived place - in Henri Lefebvre's (1991) terminology - burying the potential for conflicts that is anchored in the materiality of specific geographical places in the reductionist and highly abstract imagery of maps and diagrams.

A characteristic of this ambivalence, and a constitutive element of it, is the coexistence in the mining strategy of various lines of argumentation at distinct levels of geographical scale. A central argument refers to the global level: Relatively high international prices for minerals as well as international demand for minerals that is expected to continue growing in the foreseeable future are identified as creating a lucrative opportunity for countries such as Sweden that are endowed with natural resource wealth. A second argument refers simultaneously to the global and EU regional levels. Here, the strictly commercial premise of mineral extraction is overshadowed by issues of resource security in the EU, as competition from other parts of the world, especially from China, is identified as a potential threat to the viability of regional economic growth. The insatiability of developing nation markets, which promise great export profits for Sweden, is also construed as increasing the threat of resource scarcity in the EU. In this context, the facilitation of mining operations by the Government of Sweden is not portrayed as a national interest but rather as a regional responsibility.

Having established ever-growing global demand and Sweden's unique position as a mineral hub for the EU and therefore in need of an effective mining policy, it is paradoxical that the strategy simultaneously claims that there is a need to reduce the costs of and institutional barriers to global capital movement. Even though Sweden is portrayed as holding a trump card in what is arguably a seller's market, the strategy inexplicably concludes that the country may only be able to profit from its mineral riches by making it both cheaper and easier for companies to undertake geological exploration and establish mines. The Mineral Strategy alternates between an optimistic view of globalization as promising future export profits and a fatalistic view of global capital as an indomitable force that the Government of Sweden must placate (see, e.g., Watson, 2001, for a discussion of government perceptions of the structural constraints imposed by the movement of global capital).

Finally, the Mineral Strategy defines the expansion of mining operations in Sweden as of great interest to the local communities actually harbouring the natural resources to be extracted. As

\footnotetext{
${ }^{3}$ In the academic literature, economists have failed to find any conclusive evidence as to what constitutes an adequate tax on resource extraction (e.g., Lund, 2009; Tilton, 2004).
} 
new mines are established and old mines reopened, the strategy claims that small communities, mostly located in sparsely-populated areas of Northern Sweden that have experienced stagnating or negative demographic development for decades, will receive massive injections of both state investment and global investment capital, leading to economic growth and population increase.

\section{Analysis and results}

In what follows, we analyse the critical discourse that addresses Swedish mining policy in general and the Mineral Strategy specifically. We divide the analysis into three parts: environmental, social, and ethnic-cultural critiques. These should be seen as "moments" forming part of the same discourse, as three separate clusters around which discursive utterances coalesce. They are not mutually exclusive but exemplify different emphases. The critiques expressed, for example, in the ethnic-cultural cluster, and therefore stress only ethnic-cultural arguments, though they often relate to points expressed in the environmental cluster. The fact that the different critiques relate to each other in this way is why it is also reasonable to speak of the critical mining discourse in Sweden as a single, identifiable discourse. Note that this categorization is our own, and that the critical mining discourse could be described in other ways, for example, as comprising several sub-discourses. Also note that an economic dimension permeates all of these discursive clusters, so we have deemed it superfluous to specify this in the categorization.

\subsection{The environmental critique}

Central to the environmental critique is the perception that the Mineral Strategy prioritizes short-term economic gain for foreign mining companies while neglecting environmental considerations in an industry considered by its critics to rank among the most environmentally destructive. Critics argue that landscapes ravaged by open-pit mining will be impossible to restore after mining operations have ceased, leaving communities with poisoned watercourses, depleted natural resources, and bills for cleaning up the environment. ${ }^{4}$ Furthermore, environmental NGOs have identified mining ventures near protected areas and national parks as threatening unique environmental values, claiming that the mining industry has a history of ignoring environmental values. Another broad historical frame is offered by a critique of industrial capitalism and what is perceived as its destructive, profit-maximizing dynamic. The Mineral Strategy has been construed as just another example of 'extractivism' - i.e., colonial politics and the ruthless exploitation of the earth's finite resources. The plentiful use of suggestive, even crude, metaphors is testament to the highly confrontational mode of this critique. For example, new mining establishments in northern Sweden have been described as 'a globally organized assault' (Larsson et al., 2012) and part of a 'global hunt for the last remaining nature on earth' (Enström, 2013; see also Danielsson, 2014; Gerstenberg, 2013; Priftis, 2014; Sandling, 2013). Within this frame of industrial-capitalistic critique, the argumentation has focused on the need for fundamental change in society's overall resource use, with a move to more recycling, increased use of renewable resources, and less dependence on mineral extraction. In this way, the critical discourse has connected the Mineral Strategy and its

\footnotetext{
4 Technological development that has increased the capacity of processing plants to refine minerals, coupled with a decrease in the mineral contents of ores, has meant that the volume of mining by-products has been growing steadily through history (e.g., Bridge, 2014; Geological Survey of Sweden, 2014; Müller, 2013).
} 
perceived flaws to broader issues of social transformation in the face of environmental change, elevating the issue of the government-subsidized plundering of local communities in Sweden to a matter of global urgency (Abresparr and Harr, 2012; Abresparr, 2013a,b; Danielsson, 2013; Eriksson and Dahlberg, 2013; Gerstenberg, 2013; Harnesk, 2013a; Lundström, 2012; Mosleh, 2013; Persson, 2014; Tidholm, 2013a). Local representatives of the Social Democrats, Green Party, and Left Party joined with the youth section of the Sami parliament to accuse the national government of neglecting the interests of northern communities on behalf of business interests connected to global capital flows:

\begin{abstract}
The whole 'mining boom' amounts to a deal between the industry and the government, with the rest of us placed in the stands. A reason is the lack of a national policy supporting alternative development paths for depopulating communities. The fact is that, for example, the tourism industry has a much larger export value than does the mining industry. Yet the government prioritizes the latter over other industries, thereby continuing to lock large parts of Norrland into a relationship of dependence on the fast but shortsighted creation of job opportunities by mining establishments. The 'mining boom' is paid for socially, culturally, ecologically, and economically by local communities, while the profits disappear elsewhere. This represents unsustainable development for Norrland and for Sweden. [Harnesk et al., 2013]
\end{abstract}

Given that the crux of the critical discourse has been - contrary to the premise of the Mineral Strategy - that Sweden should extract a smaller, rather than greater, quantity of minerals, this discourse has posited several alternative development paths. First, recycling has been identified by several critics as an area largely, if not completely, neglected by the government in the Mineral Strategy. They claim that government investment in recycling technique R\&D could facilitate the large-scale reuse of metals from, for example, obsolete infrastructure, landfills, and disconnected cables (Abresparr, 2013a,b; Abresparr and Ehn, 2013; Hallberg et al., 2014; Mosleh, 2013; Olsson, 2014; Persson, 2014). Second, critics have focused on alternative land uses, claiming that there is direct conflict between industries such as tourism and recreation, fishing, agriculture, and Sami reindeer herding, on one hand, and the mining industry, on the other, and that the former are both more sustainable and, in the long term, more profitable for Sweden. Critics have therefore taken aim at what they perceive as a short-term, unsustainable policy of extractivism and instead advocate a longer-term perspective (Abresparr, 2013b; Abresparr and Harr, 2012; Elwing et al., 2014; Enström, 2013; Harnesk, 2013b; Jangvad, 2012; Larsson et al., 2012; Lindman, 2013a; Ling et al., 2013; Länta et al., 2013; Lööf, 2012; Mosleh, 2013; Persson et al., 2012). Third, some of the critics have addressed fundamental societal change, advocating a drastic shift in society's structure and basic values to allow transition from 'excessive and throw-away consumption' (Abresparr, 2013a) to something more sustainable (Abresparr, 2013b; Danielsson, 2013; Härén, 2013; Lindman, 2013b; Persson, 2014).

Several critical voices have raised the issue of ownership. Environmental NGOs, the Green Party, and local action groups claim that future generations must be accorded a right to mineral resources equal to that of the current generation. According to these critics, the Mineral Strategy is morally reprehensible in that it allows short-term interests to erode the living conditions of future Swedish citizens, both in terms of the mineral resources themselves and the environmental values compromised by mining operations (Abresparr and Harr, 2012; Enström, 2013; Gerstenberg, 2013; Jangvad, 2012; Ling et al., 2013; Mosleh, 2013; Persson et al., 2012; Sikku, 2013; Thulin, 2013; cf. Roine and Spiro, 2013a). A network called Budkavlen ('the fiery cross'), comprising local resistance groups from across Sweden, has summarized this dimension of the critique in emphatic terms:

At the moment when a nation chooses to see from a short-term perspective only, it has lost its gratitude to its ancestors and its respect for the generations to come, and then one of the very foundations of the nation has been dissolved - we must not allow for this to be our epitaph. [Persson et al., 2012] 
In response to the environmental threats posed by mining activities, critics insist that it is essential to strengthen the environmental permitting procedure. This stands in direct contrast to the Mineral Strategy, in which the government caters to the mining industry by promising to rationalize and shorten the process of granting environmental permits. Critics argue that popular protests around Sweden indicate that current environmental regulations are insufficient, contrary to the claims of both the mining industry and the government. Moreover, it is claimed that the fact that environmental impact assessments occur late in the permitting process renders them more or less beside the point (Abresparr, 2013a,b; Abresparr and Ehn, 2013; Danielsson, 2013; Eriksson and Dahlberg, 2013; Harnesk, 2013a; Jangvad, 2012; Karlsson and Vikström-Olsson, 2012; Lemker and Karlsson, 2012; Lindman, 2013a,b).

\subsection{The social critique}

The environmental critique is supported by a number of socio-economic arguments identifying the Mineral Strategy as a complete failure in terms of both state finances and local economies. Critics point out that the mineral tax of $0.05 \%$, in effect since 2005 , is negligible from a state finance perspective and that mining companies can avoid paying corporate tax in Sweden. The only possible gain to be had from an expanded mining sector would be job creation, but even this is questioned in the critical discourse. Critics, including several prominent academic economists, have claimed that jobs created in association with mining ventures tend to be shortlived and 'dearly bought', as they risk out-competing jobs in other more profitable sectors. Critics also claim that, in light of the significant investments in infrastructure and housing promised in the Mineral Strategy, the Swedish state risks paying much more than it will ever receive for the questionable privilege of attracting venture capital to its mineral-rich territories. Several critics have expressed incomprehension of the logic of a strategy that, in their view, is premised on a view of northern Sweden as simply a peripheral provider of raw materials for the centre. They conclude that the strategy can only be explained as manifesting allegiance to an outdated mode of 'neoliberalism' according to which beneficial investment conditions should by definition be promoted, regardless of a broader analysis of where the profits will accumulate (Abresparr and Harr, 2012; Bergström, 2013; Danielsson, 2013; Elwing et al., 2014; Forsberg, 2013; Fransson, 2013; Gerstenberg, 2013; Gröning, 2011; Irefalk, 2013; Jangvad, 2012; Karlsson, 2013; Leffler, 2013; Lindman, 2013b; Ling et al., 2013; Länta et al., 2013; Lööf, 2012; Persson, 2014; Persson et al., 2012; Priftis, 2014; Roine and Spiro, 2013a; Sikku, 2013; Sjöstedt, 2013a; Thulin, 2013; Tidholm, 2013a,b,c).

From a local perspective, several critics have identified the Mineral Strategy as resting on obsolete assumptions regarding job creation, as mining ventures are now highly automated and becoming even more so. In addition, the so-called economic ripple or multiplier effects of mining establishments tend to be limited. Many workers now opt to commute long-distance to and from their workplaces rather than settling in mining communities. Critics claim that, after taking account the expected costs of infrastructure, housing, and environmental clean-up, the Mineral Strategy will be highly detrimental to the local communities hosting the new mineral ventures (Danielsson, 2012; Engström and Petterson, 2013; Forsberg, 2013; Fransson, 2013; Harnesk et al., 2013; Harnesk, 2013c; Lööf, 2012; Persson et al., 2012; Persson, 2014; Tidholm, 2013b,c).

The activities of prospecting companies have been especially disturbing for several critics. The mining sector has traditionally been reserved for state-owned companies governed at least 
partly by long-term socio-economic concerns. In the new mining landscape, international venture capitalist enterprises are attracted to Sweden by the prospect of short-term profit. They use the freely available geological surveys conducted by state agencies to gain mining concessions, which they later sell for significant profit. According to critics, it was obvious that several prospecting companies never had any intention of establishing mines themselves, but wished only to inflate the value of their stocks. Prospecting activities have come to be seen as an indication that the increase in mining activities is driven by speculative interests rather than long-term national interests. In this context, the critical discourse has identified an exploitative relationship not only between the peripheral regions and southern Sweden but also between Sweden and multinational venture capitalist interests (Brännberg, 2013; Danielsson, 2013; Elwing et al., 2014; Engström and Petterson, 2013; Harnesk, 2013b; Irefalk, 2013; Jakobsson, 2013; Lindstedt, 2012; Lundberg Tourda et al., 2013; Priftis, 2014; Sjöstedt, 2013b; Tidholm, 2013b). In the eyes of its critics, the Mineral Strategy is akin to a complete sell-out of valuable natural resources to multinational companies.

\subsection{The ethnic-cultural critique}

When Clive-Sinclair Poulton, the director of Beowulf Mining, was asked how the mine planned by the company at Kallak in Jokkmokk municipality would affect the interests of the local community, he answered by pointing to a picture of a clear-felled area and rhetorically asking: 'What local people?' The utterance has since become notorious. Critics see it as symbolic of the indifference of mining companies and the Swedish government to local cultures, Sami culture in particular (Lindman, 2013a; Lundström, 2012). Current mining politics have been described in the critical discourse as a continuation, or even intensification, of the colonial policy employed by the Swedish state towards Sápmi, the Sami nation, since the sixteenth century. ${ }^{5}$ According to Sami organizations, recent mining and prospecting activities have manifested a new aggressiveness in the approach of the Swedish government to the Sami minority. As land used by Sami reindeer herdsmen has been expropriated by Beowulf Mining and other mining companies, critics see hypocrisy in the actions of a state officially condemning the oppression of minorities in other countries while actively condoning the exploitation of a minority group of its own (Irefalk, 2013; Leffler, 2013; Länta et al., 2013; Partapuoli, 2013; Persson, 2014; Priftis, 2014; Sikku, 2013; Tidholm, 2012).

Sami representatives have identified the current mining policy as an existential threat to a culture of reindeer herding that is over one thousand years old. They claim that in certain regions of northern Sweden, mining and reindeer interests are not only difficult to reconcile but in fundamental conflict. In their critique of the current mining policy, these representatives argue that the conflict is not really between the Swedish majority society and the Sami minority culture, which have developed functional modes of coexistence, but between the latter and a foreign mining industry. In this context, the critics stress the uniqueness of Sami culture and its potential value for Sweden, arguing that foreign mining companies offer little or nothing in the way of long-term benefits for the country. That the government has failed to revise the Mineral Strategy in the face of this critique is taken as evidence of its ignorance of the existential requirements of the Sami people. The Mineral Strategy has accordingly been characterized by critics as 'shameful' (Lundberg Tourda et al., 2013) and the prioritization of short-term profit

\footnotetext{
5 See Johansson (2008), Lantto (2005), Mörkenstam (2014), Persson and Öhman (2014) and Össbo and Lantto (2011) for a discussion of the settler-colonized relationship between the Swedish state and the Sami population.
} 
over the long-term survival of Sami culture as 'an enormous violation' (Lindman, 2013b; see also Danielsson, 2014; Irefalk, 2013; Lindman, 2013a; Länta et al., 2013; Partapuoli, 2013; Sikku, 2013).

Sami spokespeople have also stressed the ecological sustainability of their culture as opposed to the environmental unsustainability of the extractivism represented by the mines (Leffler, 2013; Länta et al., 2013; Sikku, 2013). However, the rhetorically most powerful argument presented in the critical discourse supporting Sami rights against the dominant interests in the mining boom is that the Swedish government has failed to uphold the international conventions on the rights of indigenous peoples that it has signed. Using this reasoning, critics of the Mineral Strategy and current mining politics have been able to cite statements by the UN Committee on the International Convention on Racial Discrimination, which has accused the Swedish government of shortcomings in respecting indigenous rights in several instances involving mineral exploration in recent years. The Swedish Supreme Court has ruled on several occasions that Sami villages can claim ownership of the territories traditionally used by them, which, according to Sami spokespeople, should imply that the Sami can veto prospecting activities on their land. These critics claim that the failure of the Swedish government to uphold this right when it conflicts with industrial interests, while being prone to self-congratulation about its democratic and human rights performance, is nothing short of disgraceful (Harnesk et al., 2013; Lindman, 2013a,b; Lundberg Tourda et al.; Länta et al., 2013; Partapuoli, 2013; Sikku, 2013; 2013). In the Sami protests against mineral extraction at important geographical locations such as Rönnbäck and Kallak, several critics observed signs of a strengthened cultural self-awareness:

\footnotetext{
These places have come to symbolize resistance to the increasingly intense exploitation of traditional Sami lands. They have come to symbolize a revitalization of the Sami culture, identity, and self-esteem. The Sami Parliament has now unequivocally pronounced that it will not accept a continuation of the exploitation we see happening today. [Harnesk et al., 2013]
}

\section{Discussion}

The discursive lines of conflict analysed here all manifest struggles for the concrete formation of geographical space through the production of geographical knowledge. As we have demonstrated, these struggles primarily concern the construction and formation of future mining communities, the construction of institutional and legal relationships between mines and the environment and between mines and native Sami communities, and the construction and regulation of capital flows between local communities, regional communities, the national government, and multinational corporations. While concerned with concrete and material futures, these discursive positions should also be understood as abstracted understandings of the geographical places being contested, or rather abstractions regarding possible alternative routes. Together they form, in Harvey's words, part of 'the battle between different levels of abstractions, between distinctively understood particularities of places and the necessary abstractions required to take those understandings into a wider realm' (Harvey, 1996: 34). In other words, while the conflicts in Swedish mining politics are based on divergent understandings of actual places, these understandings can be politicized - that is, made into an agenda for political action - only by taking abstracted forms. To take the analysis beyond mere description, we will proceed to discuss the critical discourse in terms of the abstractions - in Harvey's sense of abstracted understandings of 'particularities of places' - expressed through it, and in terms of the political alternatives to which these abstractions lead. 
To begin with, the critique takes the form of a struggle between abstractions at different spatial levels. Against the predominantly scalar abstractions constructed in the Mineral Strategy at the global, interregional, and national levels, critics posit locality and the need for a more thorough understanding of how rapid expansion of the mining sector would likely affect it. Some of the critique identifies a need to discuss the sharing of benefits such as job creation, economic growth, and the geographical distribution of mining profits, whereas other parts of the critique raise issues of territorial boundaries as mining operations threaten to harm the reindeerherding and tourism industries. The critique is directed both towards what Harvey calls 'accumulation by exploitation', as the centre is regarded as exploiting peripheral regions, and towards 'accumulation by dispossession', as critics argue that local communities are concretely deprived of land (Harvey, 2005). A separate line of criticism actualizes the subterranean scale when the Mineral Strategy and its spokespeople are criticized for privileging raw material extraction over the development of new recycling technologies (see, e.g., Elden, 2013, for a discussion of 'vertical geopolitics').

These are struggles not only at different levels of abstraction but also of different kinds (Harvey, 1996: 38). Much of the critique draws on a localized understanding of the geographical areas of potential extraction as lived places, in opposition to the highly abstracted spaces constructed in the Mineral Strategy (see Lefebvre, 1991; also Yeung, 2002). The dematerialized flows of cash and the compression of time and space characteristic of capitalism are two features that suffuse the Mineral Strategy. They are opposed by critics attempting to anchor the discussion more firmly in the local place: while jobs may be created and economic growth generated somewhere, it will not be here (see Harvey, 2005: 193ff.). This line of criticism might be construed as an opposition between two very different kinds of abstractions of temporality. The Mineral Strategy posits the mine as almost by definition wealth generating in a highly general sense in the immediate present and extending into a vaguely defined future. The Strategy's critics strive to translate the mineral deposits into a more coherent vision of the future, a vision that allows for belief in the future well-being of the local community: What happens in the near future when the mine closes, the mining jobs disappear, and the only concrete remains of the venture are its environmental problems? Finally, part of the critique attempts to abstract mineral politics into an issue of legal rights for indigenous (Sami) peoples, an aspect conspicuously absent from the Mineral Strategy. ${ }^{6}$

Clearly, the opposition to the Swedish Mineral Strategy is united by an aversion to what is understood as the government's treatment of mineral-rich areas as mere sites of extractive exploitation. However, the various lines of criticism point in different directions, making the critique appear fragmented and somewhat incoherent if read as an alternative mining policy. In fact, close reading of the critical discourse suggests a number of positions that can be derived from it, ranging from the extreme of complete renunciation of the mining industry to a far less radical critique of certain aspects of the new Mineral Strategy. As long as the critique is fragmented in this way, the chances of dialogue between the Mineral Strategy's proponents and critics are poor, as it is unclear what exactly is being proposed as an alternative. To conclude this article, we distil a concrete and coherent position from our analysis, recasting the critique in a worked-through and more easily graspable form. What, then, are the concrete alternatives to the current Swedish mining politics, as suggested by its critics?

First, a central feature of the critique is opposition to what critics claim are overly optimistic prognoses of job creation and local economic growth. This opposition can be divided into two

\footnotetext{
6 See Johansson (2008) for a fuller discussion of the status of the Sami as an ethnic minority in Sweden rather than an indigenous people.
} 
sub-arguments: 1) the jobs created will never be as numerous as claimed by mining policy proponents and, in any case, they will disappear rapidly due to automation; 2) although the forecast number of jobs might be roughly correct, most of these jobs will end up in urban centres (primarily the cities of Luleå, Umeå, and Stockholm) and not in the actual mining areas. Several studies support this line of reasoning to varying degrees (Clements and Johnson, 2000; Müller, 2015; Petkova et al. 2009; Roine and Spiro, 2013b; Rolfe et al., 2003; Rolfe et al., 2007; Sörensson, 2003; Tillväxtanalys 2010; Tonts, 2010). However, equally abundant studies demonstrate the beneficial regional impact of mineral ventures on the distribution of economic growth (e.g. Eggert 2001; Ejdemo and Söderholm, 2011; Lagos and Blanco, 2010; Rolfe et al., 2011). As the regional economic impacts seem to vary significantly depending on the characteristics of the areas targeted by mining investments (as noted by Ejdemo and Söderholm, 2011; Söderholm and Svahn, 2015), it seems safe to conclude that economic benefits for the host region can never be taken for granted beforehand. Measures must be taken to guarantee that adequate benefit-sharing mechanisms are put in place. There is also the argument that there are alternative ways to create growth and exploit natural resources, some of which risk not only being neglected but are actually jeopardized by expansion of the mining sector (e.g., ecotourism, fishing, and reindeer herding). Critics have identified one way to increase the benefits of mining for the local community and the mining regions as a whole is to establish a 'mining fund' guaranteeing that a certain proportion of the mining activity profits is used locally (e.g. Bocoum et al., 2012; Drysdale, 2008; Fischer, 2007; Roine and Spiro, 2013b). Other benefitsharing mechanisms include the establishment of employment quotas reserved for local inhabitants to safeguard against fly-in-fly-out-employment (e.g. Brereton and Parmenter, 2008, Keeping, 1998, Lewis et al., 2009).

Second, critics argue that a significant source of discontent is the actual record of mining permits (i.e., environmental permits and exploitation concessions) granted in cases in which they obviously conflict with other national interests. According to critics, several mining permits granted in recent years have clearly violated the Environmental Code provision stating that no national interest should be given priority over another in cases of conflict, but should be decided on case by case. This criticism usually targets cases in which mining interests are positioned against Sami reindeer interests. Strengthening the latter as proposed by the critical discourse would amount, at least in theory, ${ }^{7}$ to a radical shift in the institutional arrangement of mining establishments. Such arrangements would then be premised on agreements between mining companies and representatives of the national interests claimed to be jeopardized by the projects, and no project would be approved before consensus had been reached (see Össbo and Lantto, 2011, for an historical survey of how national industrial interests, in this case of hydropower development, have collided with and been given precedence over Sami reindeer husbandry interests; for further discussion, see Öhman, 2006). ${ }^{8}$

\footnotetext{
7 The institutionalization of consensus between stakeholder groups as a requirement for new mining projects would entail two main problems: 1) it would be difficult to avoid the problem of pressure from dominant interest groups in the region, as Sami representatives claimed was the case when Northland Resources mining project interests induced them to agree to a deal with the company (which filed for bankruptcy in October 2014) that was contrary to their best interests (Norberg-Juuso, 2013); 2) a representative of each national interest at stake in mining cases would have to be appointed. A recent opinion of the County Administrative Board has, for example, gone against an agreement between the mining company Norrliden Mining AB and a Sami village located near the proposed mine, as the Board ruled that the village could not be regarded as a legal representative of the reindeer industry.

8 It should be pointed out that the critical discourse, as far as Sami rights versus the mining industry are concerned, focuses firmly on reindeer husbandry interests. It could therefore be argued that the rights of Sami without reindeer are denied a voice.
} 
Critics have identified one potential solution to the above problem: granting Sami communities the right to veto mining permits in areas where mining activities would likely significantly affect reindeer husbandry or other industries. The literature provides several examples from prominent mining nations of institutional arrangements made to give local stakeholders greater influence over the process of deciding on mineral extraction ventures. In Australia, for example, the Lands Rights Act gives aboriginals in the Northern Territories effective control over activities on the land granted them, including a right to veto mineral exploration activities. Mining companies must therefore always negotiate contracts for any mining venture on territory covered by the Act (Altman, 2009). In Canada, a tripartite negotiation process has been established in many mining communities. Representatives of the community, mineral company, and government come together to discuss the viability and prospects of the proposed venture and to negotiate responsibilities and the distribution of costs and benefits (McMahon and Remy, 2001). Such institutional arrangements have allowed local stakeholders to negotiate benefits separate from the narrow issue of local job creation, which has proven difficult to regulate despite contract provisions (Browne and Robertsson, 2009; see Koivurova et al., 2015, for a review of mining legislation in relation to Sami rights in Norway, Sweden, Finland, and Russia, and Powys-White, 2015, for discussion of the need to address the inherent lack of environmental justice in the institutional relationship between settler-states and indigenous communities).

Third, much criticism addresses the apparent weakness of the Environmental Code in the procedure leading to the granting of mining permits. Crucially, the environmental impact assessment (EIA), the purported safeguard against the initiation of mining projects that significantly damage the natural environment, only enters the procedural order at a very late stage. By that stage, critics argue, the wheels are already in motion and the chances of cancelling the project plans in response to environmental risks identified in the EIA are slim to none. Possible measures would be to strengthen the role of the EIA by making it an early prerequisite for a proposed project, and to tighten the standards for approving EIAs. As Müller (2013) has demonstrated, there have been several instances in recent years when newly established mining projects have resulted in environmental damage far beyond that expected according to the EIA. A potential measure identified by critics would be to raise by a significant amount the legally required deposit for environmental restoration, regulated by the Mining Waste Directive, to ensure that the local community and/or state are not forced to pay for remedying any residual environmental damage.

A mining policy formulated in accordance with these three needs - i.e., better benefit-sharing mechanisms, a way to resolve potentially conflicting national interests, and a strengthened Environmental Code - would entail much more than marginal structural adjustments. What the critics advocate is, in fact, a complete reversal of the current policy governing the procedural order and, more importantly, its underlying ideological principles. The current policy is guided by the principle that every mineral venture is inherently favourable for Sweden; the critics' alternative policy would instead posit an institutional order in which mineral extraction is something to be avoided. In the reversed order, the primary step would be recognition of the need for fundamental lifestyle changes away from the consumer society, allowing for a decrease in metal use. The second step would be recycling metals from existing products and infrastructure, and the third would be increased use of minerals from mining waste deposits. Once the potentials of these three steps have been exhausted, the alternative mineral policy would allow further expansion of the minerals sector, but primarily through the development of existing mines - so-called brownfield projects. Only as a last resort would the establishment of new mines (i.e., greenfield projects) be considered, and then in line with an inverted localization principle. This inverted principle would mean that mining ventures would be contemplated only 
in places where the local population openly welcomes them, in contrast to the situation today, in which geological conditions are the primary determinant of mine location.

To conclude, certain aspects of current mining politics in Sweden are prompting dissent and concern among various actors throughout the country. There is therefore a pressing need to explore new ways forward, to facilitate worthwhile discussion among the interested parties. The inverted Mineral Strategy identified in the critical discourse analysed here stands little chance of gaining ground in a parliament where seven of eight parliamentary parties support the main features of the Mineral Strategy (Envall, 2015). However, we firmly believe that both proponents and opponents of the current mining policy would be well served by taking into consideration and evaluating the main lines of argument constituting the critical discourse. Doing so would also benefit the regulators who are ultimately responsible for staking out the future of Swedish mining.

\section{Acknowledgements}

The study was carried out within the project 'The transformation of Swedish mining politics: Actors, possible worlds and controversies', funded by the Swedish Research Council. 


\section{References}

Abresparr, S., 2013a. Gruvboomen öppnar för multinationella bolags vinstintressen. Västerbottenskuriren 2013-04-10.

Abresparr, S., 2013b. Gruvbrytningen bör fasas ut. VLT 2013-05-14.

Abresparr, S., Harr, M., 2012. Ge inte efter för gruvlobbyn. Svenska Dagbladet 2012-12-10.

Abresparr, S., Ehn, K., 2013. Gruvboomen ett hot mot en hållbar framtid. ETC 2013-08-02.

Altman, J., 2009. Benefit sharing is no solution to development: Experiences from mining on aboriginal land in Australia, in: Wynberg, R., Shroeder, D., Chenells, R. (Eds.), Indigenous Peoples, Consent and Benefit-Sharing: Lessons from the San-Hoodia Case. Springer, Berlin, pp. 285-302.

Anshelm, J., Galis, V., 2011. (Re)constructing nuclear waste management in Sweden: The involvement of concerned groups, in: Kumar, S. (Ed.), Integrated Waste Management. In Tech, Rijeka, pp. 401-430.

Bergström, J., 2013. Efter gruvboom kommer gruvkrasch. Värmlands Folkblad 2013-07-27.

Bocoum, B., et al., 2012. Mining Community Development Agreements: Practical Experiences and Field Studies, Vol. 3 of Mining Community Development Agreements: Source Book. World Bank, Washington DC.

Brereton, D., Parmenter, J., 2008. Indigenous employment in the Australian mining industry. J. Energy Nat. Resour. Law, 66-90.

Bridge, G., 2000. The social regulation of resource access and environmental impact: Production, nature and contradiction in the US copper industry. Geoforum 31, 237-256.

Bridge, G., 2003. Excavating nature: Environmental narratives and discursive regulation in the mining industry, in: Herod, A., Tuathail, G., Roberts, S. (Eds.), An Unruly World? Globalization, Governance and Geography. Routledge, New York.

Bridge, G., Jonas, A., 2002. Governing nature: The regulation of resource access, production, and consumption. Env. \& Planning A 34, 759-766.

Browne, M.W., Robertson, K., 2009. Benefit Sharing Agreements in British Columbia: A Guide for First Nations, Businesses and Governments, Report prepared by Woodward \& Company for the Ecosystem-Based Management Working Group, Victoria.

Brännberg, J., 2013. Regeringen i gruvspekulanternas knä. Norrbottenskuriren 2013-09-25.

Clements, K., Johnson, P., 2000. The minerals industry and employment in Western Australia: Assessing its impacts in federal electorates. Resour. Pol. 26.

Cox, K., 2005. The local and the global, in: Cloke, P., Johnson, R.J. (Eds.), Spaces of Geographical Thought: Deconstructing Human Geography's Binaries. Sage, London, pp. 175-199.

Danielsson, E., 2012. Viktigt att minerallagen ändras. Västerbottenskuriren 2012-11-13.

Danielsson, E., 2013. Skärp både miljöbalken och minerallagen. Västerbottenskuriren 2013-0608. 
Danielsson, E., 2014. Dubbla budskap från regeringen om samekulturen. Västerbottenskuriren 2014-02-07.

Deloria, V., Wildcat, D., 2001. Power and place: Indian education in America. Fulcrum Publishing.

Drysdale, J., 2008. Five principles for the management of natural resource revenue: The case of Timor-Leste's petroleum revenue. J. Energy Nat. Resour. Law 26, 151-174.

Eggert, R.G., 2001. Mining and Economic Sustainability: National Economies and Local Communities. World Business Council for Sustainable Development, Geneva, MMSD Report No. 19.

Ejdemo, T., Söderholm, P., 2011. Mining investment and regional development: A scenario-based assessment for Northern Sweden. Resour. Pol. 36, 14-21.

Elden, S., 2013. Secure the volume: Vertical geopolitics and the depth of power. Pol. Geogr. 34, 35-51.

Elwing, J., et al., 2014. Regeringen subventionerar spekulation med skattemedel. Västgötabladet 2014-01-22.

Engström, L., Petterson, L., 2013. Landsbygdspolitiken hotar både miljö och människor. ETC 2013-11-01.

Enström, N., 2013. Det finns inga gröna gruvor. Miljömagasinet 2013-05-10.

Envall, F., 2015. Storylines of progress and ambivalence. A discourse analysis of the Swedish parliamentary debate on mineral politics 1990-2015, Tema T Working paper 357, Linköping University.

Eriksson, J., Dahlberg, M., 2013. Minerallagen bör ses över. Västerbottenskuriren 2013-08-20.

Fischer, C., 2007. International Experience with Benefit-sharing Instruments for Extractive Resources. Resources for the Future, Washington, DC.

Forsberg, J., 2013. Kom och ta vad ni vill ha. Fokus 2013-09-30.

Fransson, B.U., 2013. Dags inrätta en gruvfond. Piteå-Tidningen 2013-07-18.

Geological Survey of Sweden, 2012. Beslut: Utpekande och detaljavgränsning av riksintresset Stekenjokk i Vilhelmina kommun, Västerbottens län, och Strömsunds kommun, Jämtlands län enligt 3 kap 7 paragrafen andra stycket miljöbalken 2012-12-10.

Geological Survey of Sweden, 2014. Statistics of the Swedish Mining Industry 2013, Periodiska Publikationer 2014:2.

Gerstenberg, S., 2013. För fast mark och rent vatten. Miljömagasinet 2013-05-10.

Gröning, L., 2011. Till salu nästan gratis. Expressen 2011-08-01.

Gunder Frank, A., 1967. Capitalism and underdevelopment in Latin America. Monthly Review Press.

Hallberg, R., et al., 2014. Framtidens gruva är hållbar. Svenska Dagbladet 2014-06-24.

Haraway, D., 2003. Representing reality: The critical realism project. Fem.Econ. 9, 151-160. 
Harding, S., 2006. Science and social inequality: Feminist and postcolonial issues. University of Illinois Press.

Harnesk, N., 2013a. Gruvboom hot mot miljön. Västerbottenskuriren 2013-08-07.

Harnesk, N., 2013b. Gruvboomen skapar ett sårbart samhälle. Dagens Nyheter 2013-08-08.

Harnesk, N., 2013c. Fel tänkt om mineralskatt. Norrbottenskuriren 2013-02-08.

Harnesk, N., et al., 2013. Staten och bolagen gör som de vill i norra Sverige. Svenska Dagbladet 2013-09-06.

Harvey, D., 1996. Justice, nature and the geography of difference. Blackwell, Oxford.

Harvey, D., 2000. Spaces of hope. Edinburgh University Press, Edinburgh.

Harvey, D., 2001. Spaces of capital: Towards a critical geography. Routledge, New York.

Harvey, D., 2005. The new imperialism. Oxford University Press, Oxford.

Härén, S., 2013. Ansvaret för allas hav och livsmiljö. Miljömagasinet 2013-05-24.

Irefalk, C., 2013. Fortsatt kamp om Kallak. Arbetaren 2013-08-22.

Jakobsson, J., 2013. Svenska gruvor faller platt på börsen. Svenska Dagbladet 2013-07-16.

Jangvad, I., 2012. Bromsa expanderande gruvutveckling. Västerbottenskuriren 2012-12-03.

Johansson, P, 2008. Samerna: Ett ursprungsfolk eller en minoritet?: En studie av svensk samepolitik 1986-2005. Institutionen för globala studier, Göteborgs universitet.

Keeping, J., 1998. Thinking About Benefits Agreements: An Analytical Framework, Northern Minerals Program Working Paper No. 4. The Canadian Arctic Resources Committee, Ottawa.

Karlsson, M., Vikström-Olsson, S., 2012. Nu överklagar vi Bungedomen. Svenska Dagbladet 201208-02.

Karlsson, S.O., 2013. Gropen som blir kvar. Expressen 2013-10-06.

Koivuroa, T. 2015. Legal protection of Sami traditional livelihoods from the adverse impacts of mining: A comparison of the level of protection enjoyed by Sami in their four home states. Arctic Rev. Law and Pol. 6.

Lagos, G., Blanco, E., 2010. Mining and development in the region of Antofagasta. Resour. Pol. 35, $265-275$.

Lantto, P. 2005. Raising their voices: The Sami movement in Sweden and the Swedish Sami policy 1900-1960, in: Leete, A., Valk, U. (Eds.), The Northern Peoples and States: Changing Relationships. Tartu University Press: Tartu.

Larsson, J. et al., 2012. Gruvdrift hot mot fisketurismen. Norrbottenskuriren 2012-06-02.

Leffler, M., 2013. Bolagen rånar våra marker på mineraler. Miljömagasinet 2013-03-15.

Lefebvre, H., 1991. Production of space. Blackwell, Oxford.

Lemker, H., Karlsson, M., 2012. LKAB bör betala för nya bostäder. Svenska Dagbladet 2012-1205 . 
Lewis, M., Brocklehurst, S., McNair, D. (Eds.), 2009. Aboriginal Mining Guide: How to Negotiate Lasting Benefits for Your Community. Canadian Centre for Community Renewal, Port Albemi.

Lindman, E., 2013a. Kampen om Kallak. Arbetaren 2013-10-04.

Lindman, E., 2013b. Historiens upprepning. Arbetaren 2013-12-13.

Lindstedt, G., 2012. Vadå, gruvskatt? Veckans Affärer 2012-06-14.

Ling, M., et al., 2013. Orörd fjällmiljö eller gruvboom. Norrbottenskuriren 2013-09-30.

Lund, D., 2009. Rent taxation for nonrenewable resources. Ann. Rev. Resour. Econ., 1, 287-308.

Lundberg Tourda, T. et.al., 2013. Dagens gruvpolitik är ovärdig Sverige. Aftonbladet 2013-09-05.

Lundström, E., 2012. Gruvmotståndets röster möttes i Stockholm. Internationalen 2012-12-05.

Länta, M., et al., 2013. Sverige skänker bort tillgångar i Sameland. Dagens Nyheter 2013-08-21.

Lööf, H., 2012. Kalkbrottet kommer att bli dyrt för Gotland. Svenska Dagbladet 2012-08-31.

McMahon G., Remy F., (Eds.), 2001. Large Mines and the Community: Socio-economic and Environmental Effects in Latin America, Canada and Spain. World Bank, Washington, DC.

Mosleh, N., 2013. Hållbar för sju generationer. Västerbottenskuriren 2013-11-06.

Müller, A., 2013. Smutsiga miljarder: Den svenska gruvboomens baksida. Ord \& Visor, Skellefteå.

Müller, A., 2015. Norrlandsparadoxen. Ord \& Visor, Skellefteå.

Mörkenstam, U., 2014. The constitution of the Swedish Sami people: Swedish Sami policy and the justification of the inner colonization of Sweden, in: Tripathy, J., Padmanabhan, S. (Eds.), Becoming Minority: How Discourses and Policies Produce Minorities in Europe and India. Sage, London, pp. 88.110.

Norberg-Juuso, L., 2013. Ett nej hade varit socialt självmord. Norrländska Socialdemokraten 2013-08-30.

Olsson, E., 2014. Återvinning i toppklass - Ändå växer sopberget. Dagens Nyheter 2014-07-17.

Partapuoli, P.J., 2013. Samer måste få styra Sapmi. Svenska Dagbladet 2013-10-26.

Persson, M., 2014. Dags att ändra vår utarmande svenska minerallagstiftning. Västerbottenskuriren 2014-01-25.

Persson, M. et al., 2012. Du gamla du fria - där 'fria' står för gratis. Svenska Dagbladet 2012-1113.

Persson, M., Öhman, M-B., 2014. Vision for a future at the source of the Ume river, Sweden: The battle against the Rönnbäck nickel mining project, in: Gärdebo, J. et al. (Eds.), RE: Mindings: Coconstituting indigenous, academic, artistic knowledges. Uppsala University Press: Uppsala, pp. 103-119.

Petkova, V., Lockie, S., Rolfe, J., Ivanova, G., 2009. Mining developments and social impacts on communities: Bowen Basin case studies. Rural Soc. 19, 211-228.

Powys-White, K. 2015. Indigenous food-systems, environmental justice, and settler-industrial states, in: Rawlinson, M., Ward, C., (Eds.), Global Food, Global Justice. Cambridge Scholar Publishing, Cambridge, pp. 143-167. 
Priftis, M., 2014. Vem är det som är egenmäktig? Svenska Dagbladet 2014-02-26.

Roine, J., Spiro, D., 2013a. Hög tid att höja avgifterna för gruvbrytning i Sverige. Dagens Nyheter 2013-11-14.

Roine, J., Spiro, D., 2013b. Utvinning för allmän vinning: En ESO-rapport om svenska mineralinkomster. Cabinet Office, Ministry of Finance.

Rolfe, J., Gregg, D., Ivanova, G., Lawrence, R., Rynne, D., 2011. The economic contribution of the resources sector by regional areas in Queensland. Econ. Anal. Policy 41, 15-36.

Rolfe, J., Lockie, S., Franettovich, M., 2003. Economic and Social Impacts of the Coppabella Mine on the Nebo Shire and the Mackay Region. Final Report prepared for Australian Premium Coals Pty Ltd, Queensland, Australia.

Rolfe, J., Lockie, S., Ivanova, G., 2007. Lessons from the social and economic impacts of the mining boom in the Bowen Basin 2004-2006. Austr. Journ. Reg. Stud. 13.

Said, E., Orientalism, 1979. Vintage Books.

Sandling, E.S., 2013. Betydelsen är vad som händer idag och i framtiden. Norrbottens-kuriren 2013-08-12.

Schandl, H. , Darbas, T., 2008. Surat Basin Scoping Study. Enhancing Regional and Community Capacity for Mining and Energy Driven Regional Economic Development. Report to the Southern Inland Queensland Area Consultative Committee and Australian Government Department of Infra-structure, Transport, Regional Development and Local Government, CSIRO Sustainable Ecosystems, Canberra.

Sikku, 0.J., 2013. Gruvexploatering i Sapmi. Miljömagasinet 2013-08-09.

Sjöstedt, J., 2013a. Vi ska ta betalt för våra mineraltillgångar. Norrbottenskuriren 2013-10-15.

Sjöstedt, J., 2013b. Vi måste ta mer betalt för våra naturresurser. Aftonbladet 2013-01-23.

Smith, N., 1991. Uneven development: Nature, Capital and the Production of Space, second ed. Blackwell, Oxford.

Storey, K., 2001. Fly-in/Fly-out and Fly-over: Mining and regional development in Western Australia. Aust. Geogr. 32, 133-148.

Swedish Ministry of Enterprise and Innovation, 2013. Sveriges mineralstrategi: För ett hållbart nyttjande av Sveriges mineraltillgångar som skapar tillväxt i hela landet. Regeringskansliet, Stockholm.

Swedish National Audit Office, 2015. Mining waste: Financial risks for the state. Report Number 2015: 20. SNAO, Stockholm.

Swyngedouw, E., 2007. Impossible/undesirable sustainability and the post-political condition, in: Krueger, R., Gibbs, D. (Eds.), The Sustainable Development Paradox. Guilford Press, New York, pp. 13-40.

Söderholm, P., Svahn, N., 2015. Mining, regional development and benefit-sharing in developed countries. Resour. Pol. 45, 78-91.

Sörensson, R., 2003. Effektstudie av gruvetableringar i Lycksele och Storumans arbetsmarknadsregioner, CERUM Report II. Umeå Universitet, Umeå. 
Thulin, S., 2013. Gamla näringar och nya ska lyfta Sverige. Riksdag och departement 2013-11-25.

Tidholm, P., 2012. Gruvligt svek mot samerna. Aftonbladet 2012-12-01.

Tidholm, P., 2013a. När Sverige reade ut sina tillgångar. Västerbottenskuriren 2013-08-24.

Tidholm, P., 2013b. Sverige skänker bort bergets guld. Dagens Nyheter 2013-09-23.

Tidholm, P., 2013c. Det nya gruvupproret. Expressen 2013-08-10.

Tillväxtanalys, 2010. Malmfälten under förändring: En rapport om arbetskraftsförsörjning och utvecklingsmöjligheter i Gällivare, Kiruna och Pajala. Slutrapport regeringsuppdrag, dnrN2009/6900/FIN; Rapport 2010/05.

Tilton, J., 2004. Determining the optimal tax on mining. Natural Resources Forum, 28, 144-149.

Tonts, M., 2010. Labour market dynamics in resource dependent regions: An examination of the Western Australian gold fields. Geogr. Res. 48, 148-165.

Watson, M., 2001. International capital mobility in an era of globalization. Politics 21, 81-92.

World Economic Forum, 2013. Responsible Mineral Development Initiative 2013, Geneva.

Yeung, H., 2002. The limits to globalization theory: A geographic perspective on global economic change. Econ.Geogr.78, 285-305.

Öhman, M-B. 2006. On visible places and invisibilized peoples: Swedish state-supported hydropower exploitation of indigenous peoples' territories, in: Baraldi et al. (Eds.), Taking Place: The Spatial Contexts of Science. Science History Publications, Sagamore Beach, pp. 189-221.

Össbo, Å., Lantto, P. 2011. Colonial tutelage and industrial colonialism: Reindeer husbandry and

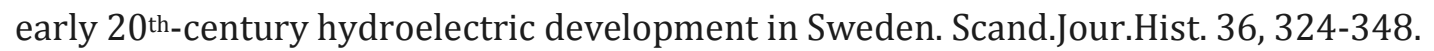

Özkaynak, B., et al., 2012. Mining Conflicts Around the World: Common Grounds From an Environmental Justice Perspective, EJOLT Report no.7. The Environmental Justice Organisations, Liabilities and Trade Project. 